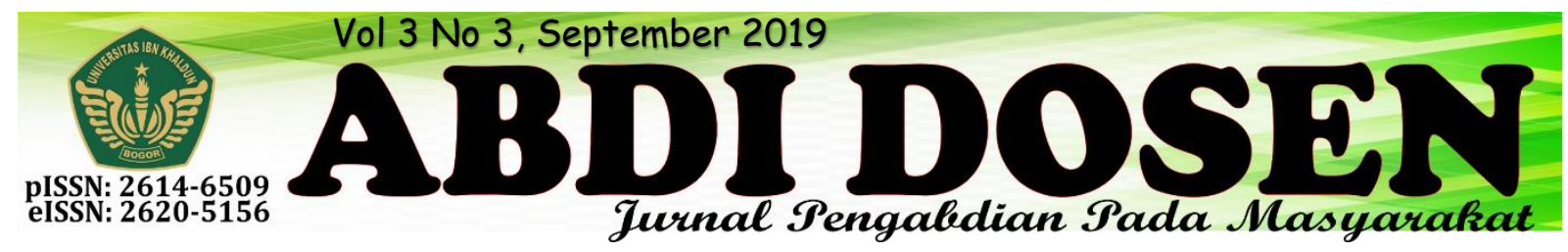

\title{
PEMBERDAYAAN MASYARAKAT MELALUI PENINGKATAN KUALITAS PENDIDIKAN, AGAMA, EKONOMI, KESEHATAN, HUKUM DAN LINGKUNGAN DI DESA CIBITUNG WETAN
}

\author{
Hendri Maulana ${ }^{1}$, Siti Halimah ${ }^{2}$ \\ endry@uika-bogor.ac.id ${ }^{1}$ \\ sitihal7953@gmail.com ${ }^{2}$ \\ Fakultas Ekonomi dan Bisnis Universitas Ibn Khaldun ${ }^{1}$, Mahasiswa KKN Kelompok 40 tahun $2018^{2}$
}

\begin{abstract}
ABSTRAK
Pemberdayaan masyarakat adalah proses pembangunan di mana masyarakat berinisiatif untuk memulai proses kegiatan sosial dengan memperbaiki situasi dan kondisi pembangunan atau dikenal juga sebagai subjek motor penggerak. Sesuai dengan Tri Darma Perguruan Tinggi, hasil mempelajari teori adalah apikasi mahasiswa diharapkan lebih dekat dengan masyarakat, mampu belajar dari masyarakat, membantu memecahkan permasalahan yang ada, mengabdi dan memberdayakan masyarakat. Tujuan dalam pemberdayaan masyarakat ini yaitu memperbaiki dan meningkatkan kualitas yang ada desa melalui pemberdayaan pendidikan, kesehatan, ekonomi, hukum dan lingkungan. Adapun untuk mencapai pemberdayaan kualitas masyarakat tersebut melalui kegiatan penyuluhan, diskusi, pengajian dan penyampaian informasi melalui penyebaran pesan. Penyampaian pesan atau materi penyuluhan menggunakan bahasa yang mudah dimengerti dengan menggunakan media pendukung, seperti media cetak, media elektronik, dan media luar. Kegiatan pemberdayaan yang dilakukan sudah sesuai harapan dengan meningkatnya kualitas masyarakat.
\end{abstract}

\section{Kata Kunci : Pemberdayaan, Kualitas, Perubahan}

\section{PENDAHULUAN}

Pemberdayaan menurut kamus besar Bahasa Indonesia (KBBI, 2008) adalah proses, cara, membuat, memberdayakan dari kata daya yaitu kemampuan melakukan sesuatu atau kemampuan untuk bertindak. Pemeberdayaan dilakukan dalam upaya peningkatan kualitas kesejahteraan masyarakat meliputi kesejahteraan keluarga, memandirikan masyarakat miskin, mengangkat harkat dan martabat masyarakat lapisan bawah, menjadikan masyarakat sebagai subjek dalam bertindak.

Pemeberdayaan dapat dilakukan oleh masyarakat sebagai subjek dalam bertindak. Pemberdayaan masyarakat ini melalui peningkatan kualitas pendidikan, agama, ekonomi, kesehatan, hukum dan lingkungan di Desa Cibitung Wetan Kecamatan Pamijahan Kabupaten Bogor. Melalui program ini kami tim Kuliah Kerja Nyata Kelompok 40 Universitas Ibn Khaldun, berupaya untuk melaksanakan program pengabdian masyarakat yang terbentuk dalam sebuah program pemberdayaan masyarakat melalui peningkatan kualitas pendidikan, agama, ekonomi, kesehatan, hukum dan lingkungan di Desa Cibitung Wetan Kecamatan Pamijahan Kabupaten Bogor. Dimana 
program ini tidak hanya memberikan ilmu tapi juga memberikan wawasan serta keterampilan yang dapat digunakan oleh masyarakat meningkatkan kualitas di Desa Cibitung Wetan.

\section{Keadaan Geografis}

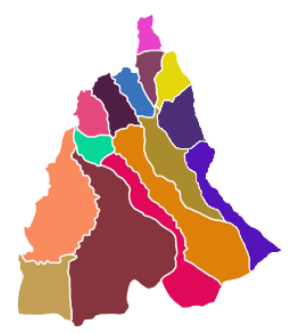

a. Luas Daerah :12.532,36 H

b. Batas Administrasi :

Batas Utara : Kecamatan Cibungbulang Batas Barat : Kecamatan Leuwiliang Batas Selatan : Kabupaten Sukabumi Batas Timur : Kecamatan Tenjolaya c. Terdiri dari 8 Desa, Yaitu :

1. Desa Cibunian

2. Desa Purwabakti

3. Desa Ciasmara

4. Desa Gunung Sari

5. Desa Gunung Bunder 2

6. Desa Gunung Bunder 1

7. Desa Cibening

8. Desa Gunung Picung

9. Desa Cibitung Kulon

10. Desa Cibitung Wetan

11. Desa Pamijahan

12. Desa Pasarean

13. Desa Gunung Menyan

14. Desa Cimayang

15. Desa Ciasihan

\section{Kondisi Masyarakat}

Masyarakat di Desa Cibitung Wetan mempunyai beberapa kondisi dalam berbagai aspek, seperti dalam segi : Agama, masyarakat di desa Cibitung wetan memiliki kekentalan dalam beragama sebagaimana dicirikan dengan adanya kegiatan - kegiatan yang islami dan kepedulian untuk memperhatikan setiap kegiatan siraman rohani diantaranya seperti kegiatan: pengajian. Dimana pengajian yang ada di desa Cibitung Wetan terdiri mulai dari pengajian anak-anak, pengajian pemuda dan pemudi, pengajian ibu-ibu dan bapak-bapak.

Kegiatan pengajian tersebut menjadi kegiatan rutin dalam segi keagamaan, selain adanya kegiatan rutin di desa Cibitung Wetan terdapat agenda kerohanian seperti pengajian tabligh akbar (pengajian besar yang dilaksanakan di minggu pertama awal bulan.

Kondisi pendidikan yang ada di desa Cibitung Wetan sudah berkembang terlihat dari kesadaran masyarakat yang secara garis besar orang tua mampu menyekolahkan dan memberikan dukungan anak-anak nya ke jenjang yang lebih tinggi.

Adapun keadaan ekonomi warga desa Cibitung Wetan relatif menengah terbukti dari hasil panen yang selalu melimpah dikarnakan kesuburan tanahnya, namun kesadaran dalam memanfaatkan sumber daya alam sangat minim dan banyak sekali masyarakat yang pada akhirnya bekerja di luar dari desa, bahkan dari kecamatan Pamijahan.

Kondisi kesehatan yang ada di desa Cibitung Wetan sudah sangat terbantu dengan adanya Puskesmas Pembantu yang disediakan oleh Pemerintah Desa Cibitung Wetan. Penyuluhan gizi sudah sering dilaksanakan di desa cibitung wetan sehingga relatif tidak terjadi gizi buruk. Standar kesehatan sudah tercapai dengan adanya pengembangan dan kesuburan air bersih dan pertanian padi. 


\section{METODE PENGABDIAN}

Tahapan pelaksanaan untuk kegiatan ini sebagaimana terlihat pada bagan sebagai berikut:

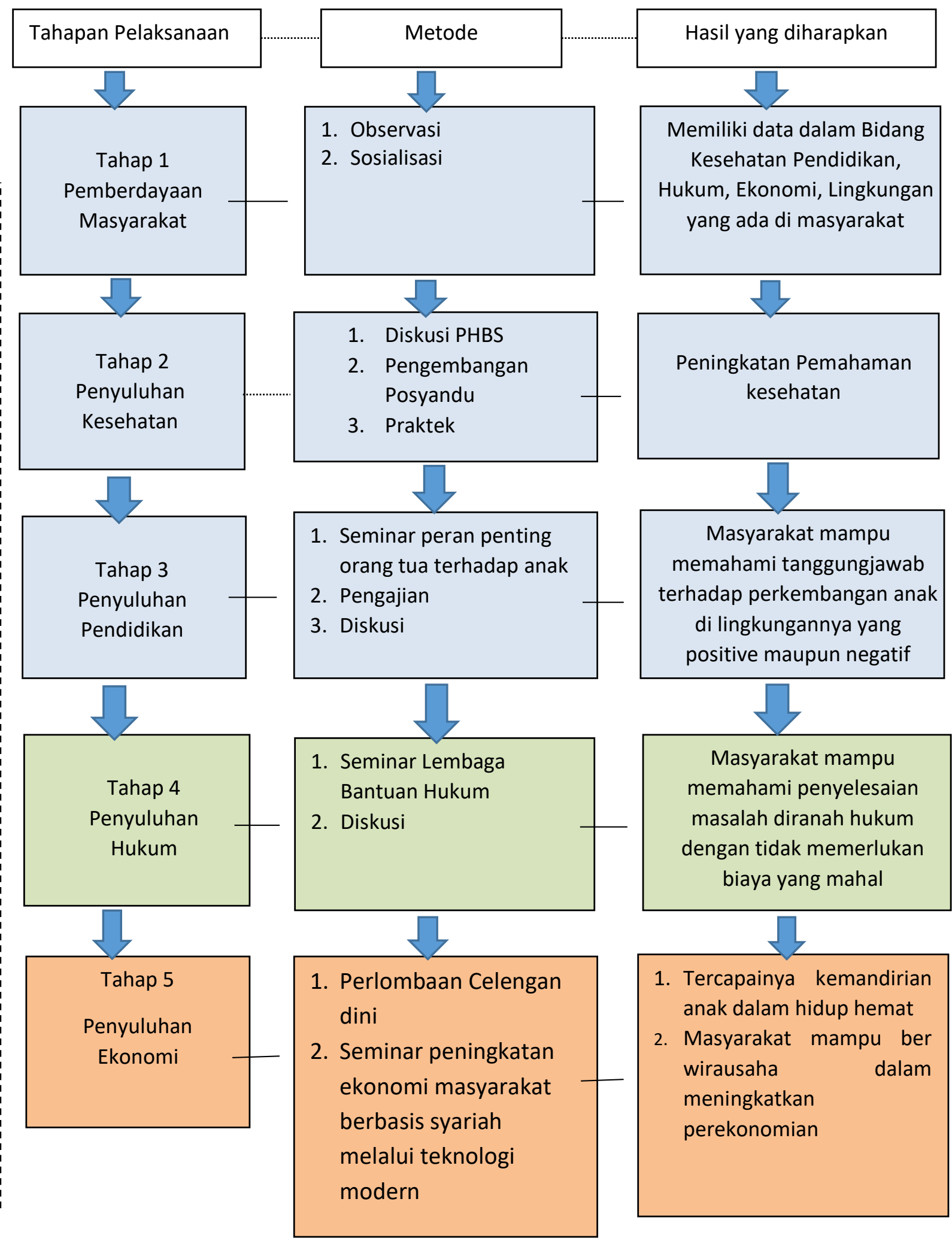




\section{Jadwal Kegiatan}

\begin{tabular}{|c|c|c|c|c|c|}
\hline \multirow{2}{*}{ No. } & \multirow{2}{*}{ Kegiatan } & \multicolumn{4}{|c|}{ Minggu } \\
\hline & & 1 & 2 & 3 & 4 \\
\hline 1 & Penyusunan Rencana kegiatan & & & & \\
\hline 2 & Sosialisasi Rencana kegiatan & & & & \\
\hline 3 & Gotong Royong bersama warga & & & & \\
\hline 4 & Penyuluhan PHBS & & & & \\
\hline 5 & Perlombaan 17 Agustus & & & & \\
\hline 6 & $\begin{array}{l}\text { Seminar Peran Penting Orang Tua dalam } \\
\text { mendidik Anak }\end{array}$ & & & & \\
\hline 7 & $\begin{array}{l}\text { Penyuluhan Peningkatan Ekonomi dan } \\
\text { Ekonomi Syari'ah }\end{array}$ & & & & \\
\hline 8 & Seminar Lembaga Bantuan Hukum & & & & \\
\hline 9 & Pelatihan Microsoft Office & & & & \\
\hline 10 & Pengajaran TPA, SD, MI, SMP & & & & \\
\hline 11 & Penyuluhan Kenakalan Remaja & & & & \\
\hline 12 & Pemetaan RW 02 Ds Cibitung Wetan & & & & \\
\hline 13 & Bimbel Agama dan Bahasa Inggris & & & & \\
\hline 14 & Monitoring dan Evaluasi & & & & \\
\hline 15 & Penyusunan laporan & & & & \\
\hline
\end{tabular}

\section{Metode Pendekatan}

Pendekatan yang digunakan dalam kegiatan ini adalah

a. Pendekatan Religius, yaitu pendekatan dimana seluruh jama'ah majlis ta'lim nurul abror menghadiri acara pertemuan dengan mahasiswa kkn.

b. Pendekatan Organisasi, yaitu pendekatan dimana seluruh kegiatan diorganisir oleh oleh paguyuban pemuda cikasungka (PPC) tentang pemberdayaan masyarakat terhadap kesehatan, pendidikan dan kreatifitas.

c. Pendekatan Kekerabatan, yaitu pembinaan yang dilakukan senantiasa dikaitkan dalam rangka meningkatkan kesadaran akan pentingnya pendidikan, kesehatan, dan lingkungan

d. Pendekatan berdasarkan karakter masyarakat, yakni pembinaan yang dilakukan akan disesuaikan dengan karakter masyarakat setempat, sehingga masyarakat dapat berpartisipasi langsung terhadap kegiatan-kegiatan yang akan dilaksanakan.

\section{Partisipasi Masyarakat}

Partisipasi masyarakat yang dapat dilakukan dalam kegiatan ini adalah sebagai berikut:

a. Mempersiapkan warga yang bersedia mengikuti pembinaan baik tentang pemberdayaan tentang kesehatan, pendidikan dan kreatifitas.

b. Mempersiapkan tempat untuk pemberdayaan tentang kesehatan, pendidikan dan kreatifitas.

c. Mempersiapkan tempat untuk pelaksanaan penyuluhan kesehatan.

d. Pelaksana kegiatan penyuluhan kesehatan, pendidikan dan kreatifitas bersama-sama dengan Tim Pengusul melakukan monitoring pelaksanaan 


\section{Langkah Evaluasi}

Evaluasi yang akan dilakukan terdiri dari:

a. Evaluasi proses, yang terkait dengan perencanaan, pelaksanaan dan monitoring kegiatan. Evaluasi proses akan dilakukan setiap pekan bersama dengan masyarakat.

\section{REALISASI PROGRAM}

Dalam pelaksanaan kegiatan KKN Tematik Terintegrasi Universitas Ibn Khaldun Bogor di Desa Cibitung Wetan, Kecamatan Pamijahan, Kabupaten Bogor Kami membuat beberapa rangkaian program kerja yang Alhamdulillah berjalan lancar sesuai dengan rencana, diantaranya:

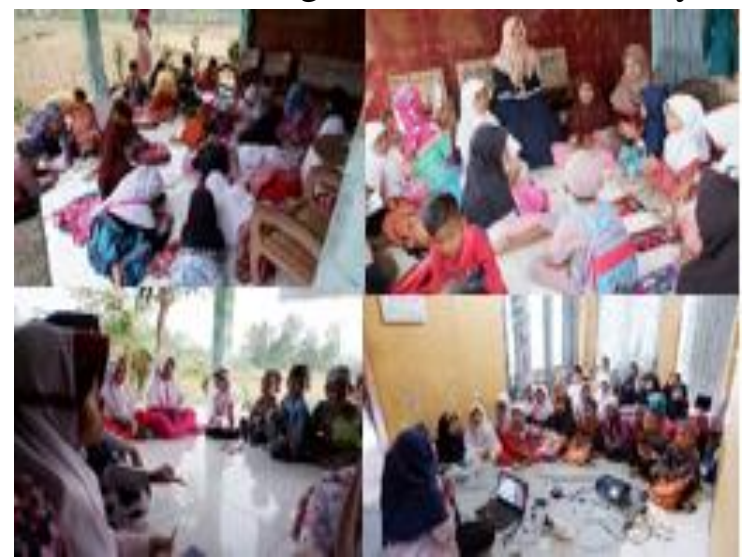

a. Kegiatan pengajian rutinan yang diadakan setiap senin-rabu yang diikuti anak-anak, tujuan dari kegiatan ini untuk menambah iman dan ilmu tentang agama islam.

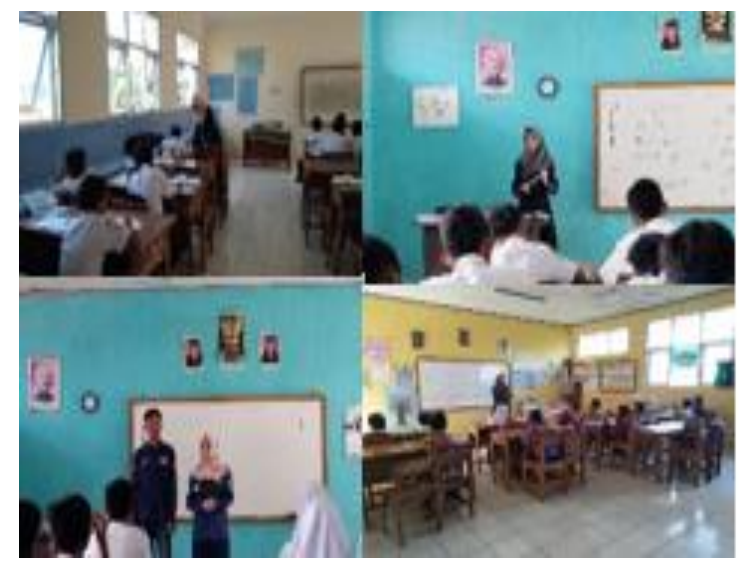

b. Kegiatan belajar mengajar di beberapa sekolah (PAUD, MI, dan MTs). b. Evaluasi hasil, yang akan dilaksanakan setelah kegiatan dilaksanakan. Evaluasi hasil ditujukan meningkatkan kesadaran tentang pentingnya kesehatan, pendidikan dan kreatifitas kepada warga.

Mengajar disekolah dengan metode pembelajaran yang efektif dan efisien diharapkan materi belajar lebih cepat diserap siswa/i.

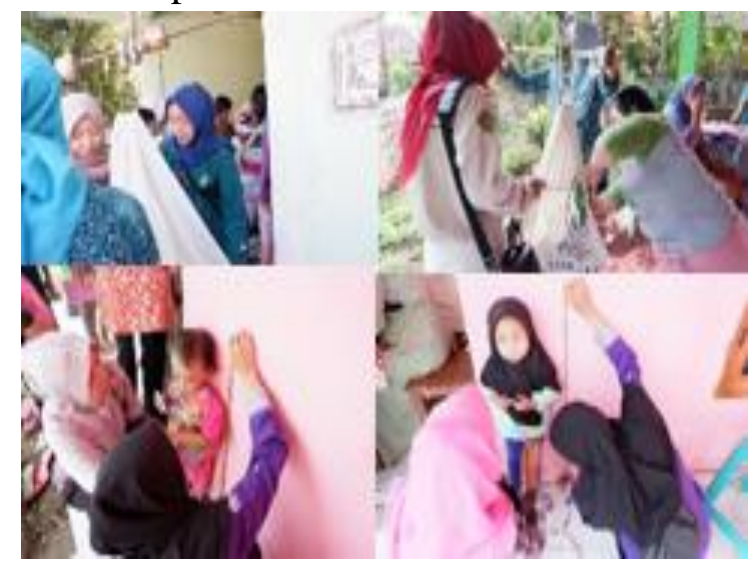

c. Kegiatan pengembangan posyandu dan penyuluhan PHBS ini bertujuan untuk mampu mengenali, mencegah dan mengatasi permasalahan kesehatan yang dihadapi serta menjaga dan memeliharan kesehatan dan pertumbuhan pada anak/balita di desa cibitung wetan kecamatan pamijahan kabupaten bogor, proses sosialisasinya kepada seluruh kader PKK di desa tersebut, masyarakat yang hadir untuk mengetahui kondisi pertumbuhan. Kegiatan ini sangat membantu dan berdampak positif terlihat dari pertumbuhan anak yang berkembang baik dan terbebas dari gangguan kesehatan yang dihadapi. 


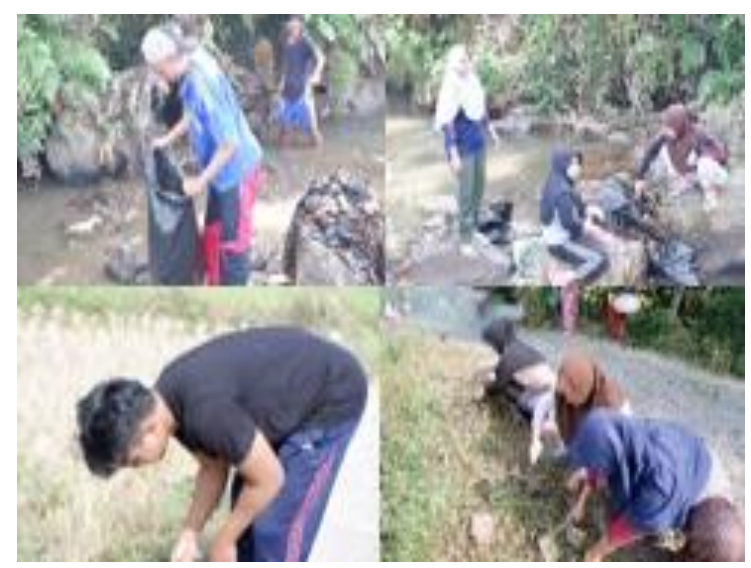

d. Kegiatan gotong royong yang bekerjasama dengan pemuda Karang Taruna dan RW setempat dalam membantu menjaga kebersihan Kp. Gardu Barat khususnya di aliran sungai, dikarenakan aliran sungai tersebut biasa digunakan oleh warga untuk mencuci pakaian.

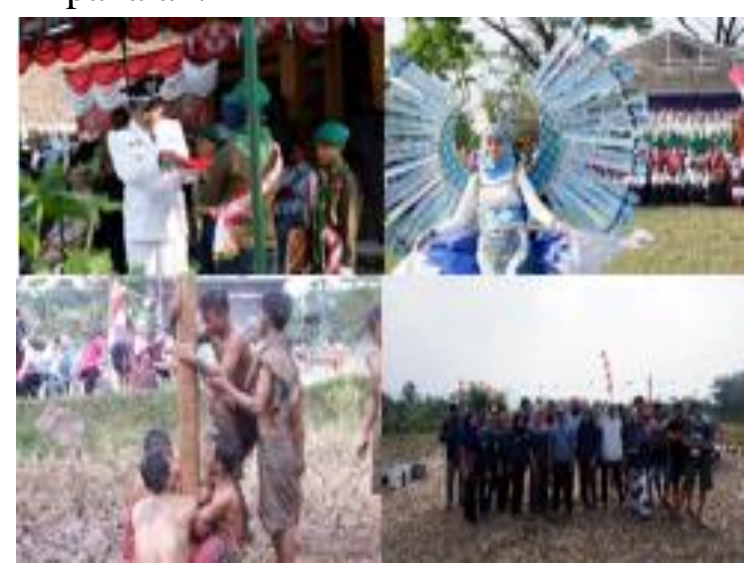

e. Kegiatan pemeriahan HUT RI ke-73 di lapangan Desa Cibitung Wetan dan Kp. Gardu Barat. Ikut berpartisipasi dengan Karang Taruna Desa dalam memeriahkan HUT RI

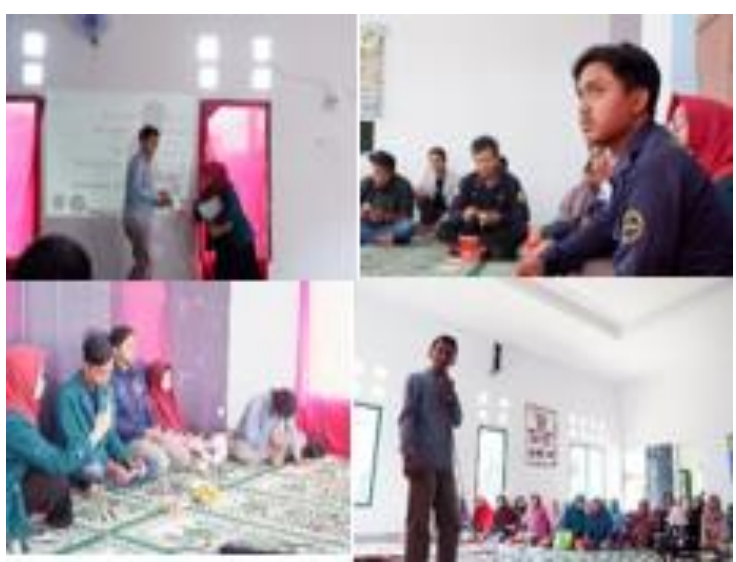

f. Kegiatan Penyuluhan program kerja ekonomi yang bekerjasama dengan ekonomi syariah, kegiatan ini bertujuan untuk meningkatkan perekonomian dengan cara berwirausaha memanfaatkan sumber daya alam yang ada.

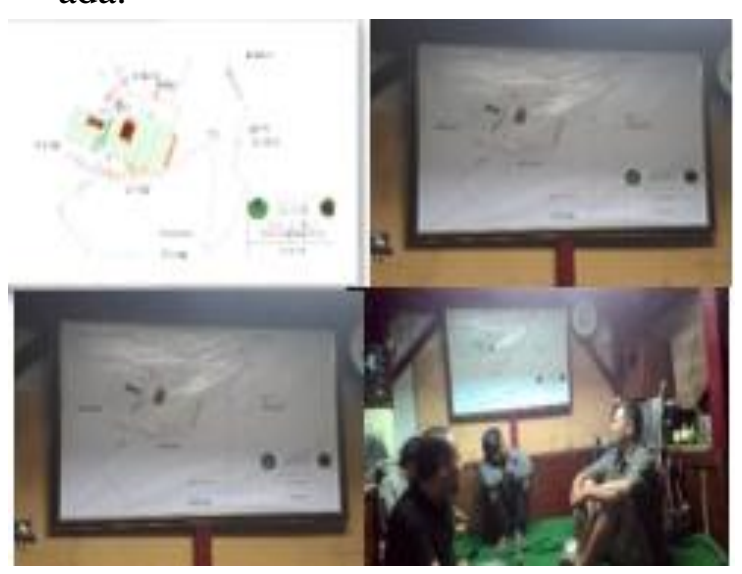

g. Pemetaan Peta RW 02. Kegiatan berbentuk fisik ini memudahkan para pegunjung untuk mengetahui wilayah dan menunjukkan lokasi / akses jalan tempat rumah ibadah, rumah ketua RT/RW dan rumah karang taruna desa. 


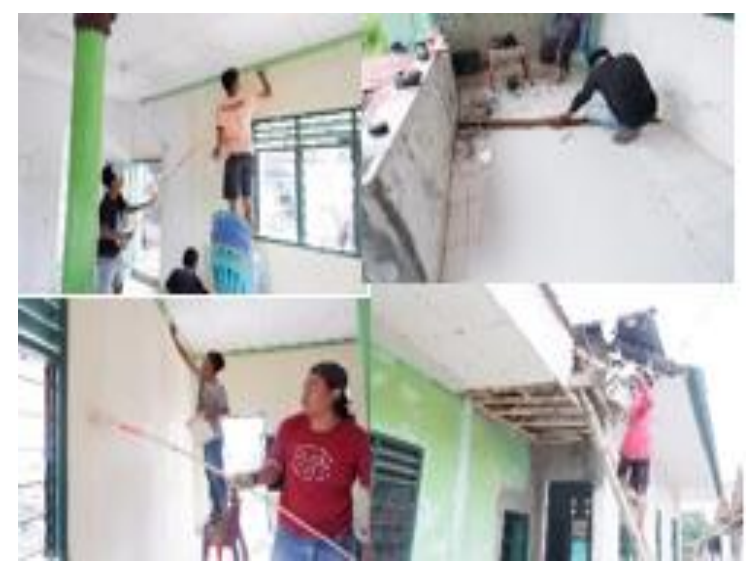

h. Kegiatan Renovasi Majelis yang bekerja sama dengan DKM dan masyarakat setempat, program kerja yang berbentuk fisikn tersebut bertujuan untuk meningkatkan peran dan fungsi masjid dalam pelaksanaan ibadah serta menanamkan nilai-nilai ajaran agama dalam rangka mewujudkan akhlaqul kharimah bagi warga yang bersifat sosial, dakwah pendidikan Islam yang bertafaquh fiddin

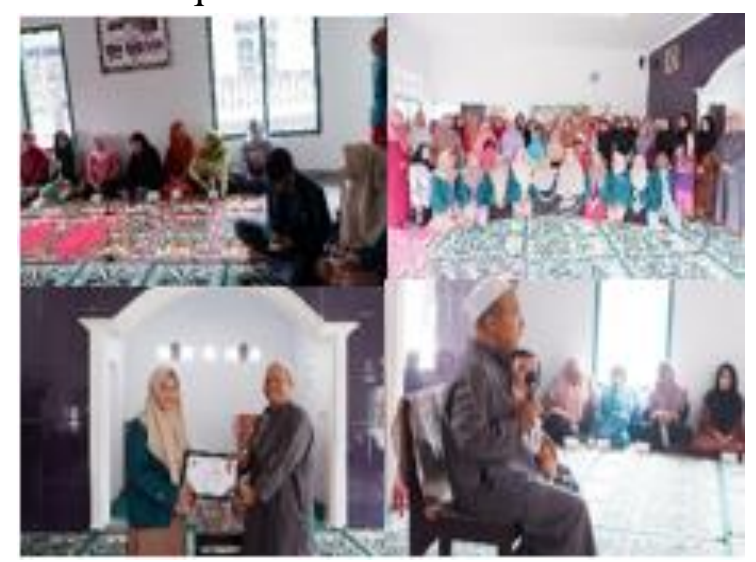

i. Penyuluhan peran penting orang tua terhadap anak, Pentingnya peran orang tua terhadap pendidikan anak bukan hal yang biasa karena pendidikan adalah modal utama yang harus dimiliki oleh setiap individu untuk menghadapi perkembangan zaman, Kegiatan ini bertujuan untuk meningkatkan peran dan tanggung jawab masyarakat khususnya orangtua terhadap perkembangan anak dengan melihat potensi dan bakat yang ada pada anak.

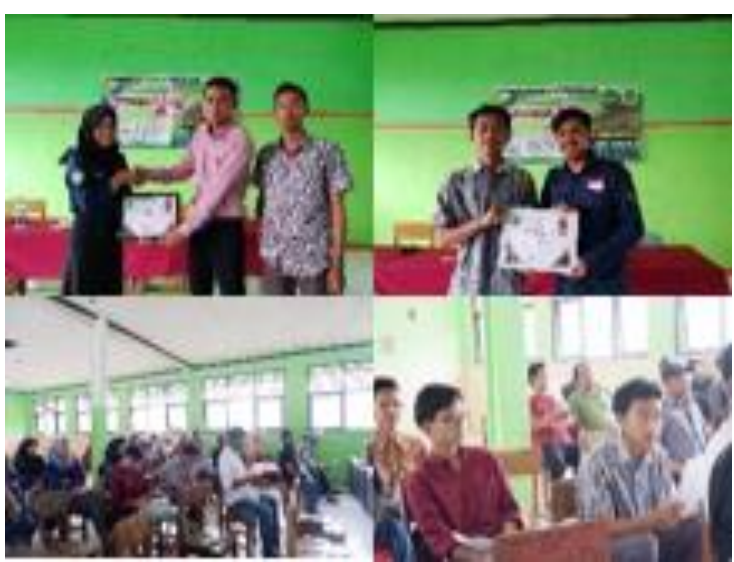

j. Seminar peran dan fungsi Lembaga Bantuan Hukum (LBH), bertujuan memperkenalkan LBH yang merupakan jalur bagi masyarakat kalangan menengah kebawah untuk berkonsultasi mengenai masalah hukum yang sedang dihadapi.

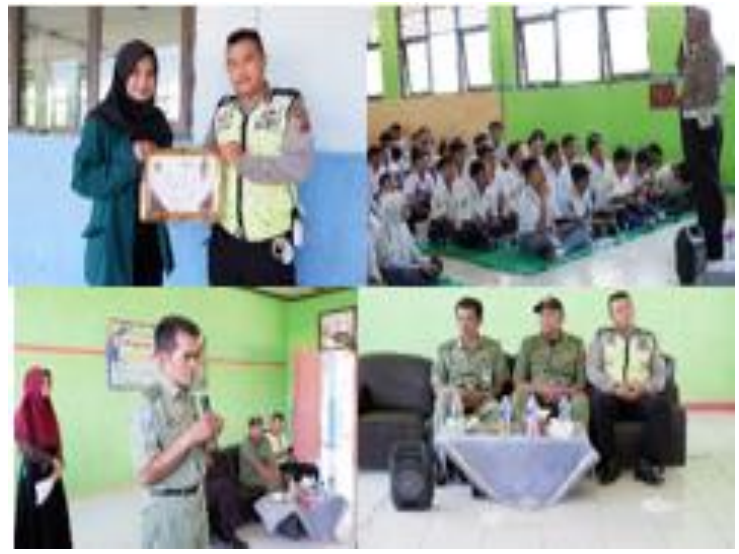

k. Penyuluhan Kenakalan Remaja, bertujuan untuk menyadarkan siswasiswi setempt bahwa perlu berhati-hati dalam pergaulan yang ada dilingkungan keluarga, masyarakat, maupun sekolah.

1. Pelatihan Microsoft Office Mengembangkan pengetahun masyarakat khususnya peserta didik yang ada di Desa Cibitung Wetan terhadap pentingnya penguasaan teknologi informasi dan komputer saat ini dengan mengajarkan bagaimana menggunakan software-software yang dapat digunakan sehingga jika suatu saat diperlukan akan dapat dengan cepat dan mudah untuk diakses. 


\section{KESIMPULAN}

Kuliah Kerja Nyata merupakan sarana bagi mahasiswa untuk menyalurkan potensinya sebagai agen perubahan. Peran mahasiswa yang mampu melakukan berbagai aksi untuk menjadi bagian dari agen perubahan (agent of change) yang signifikan terhadap desa yang dijadikan sebagai objek KKN. Karenanya KKN dijadikan program rutin hampir sebagian besar kampus-kampus di Indonesia dan dijadikan sebagai syarat kelulusan untuk mahasiswa. Termasuk di Universitas Ibn Khaldun Bogor yang juga mengadakan program KKN yang terbagi dalam beberapa kelompok. Salah satunya kelompok 40 yang bertempat di Kecamatan Pamijahan. KKN yang dilaksanakan oleh Kelompok 40 bertempat di Kp Gardu Barat Desa Cibitung Wetan Kecamatan Pamijahan Kabupaten Bogor. Pelaksanaanya Berawal dari tanggal 7 Agustus sampai dengan 5 September 2018.

Adapun program kerja dirancang setelah melihat berbagai potensi yang bisa dikembangkan di Desa yang dijadikan objek KKN. Program kerja tersebut terdiri dari 5 program, diantaranya program pendidikan, kesehatan, ekonomi, hukum, dan lingkungan hidup, dan program kemanusiaan yang terangkai dalam berbagai acara dalam setiap harinya selama satu bulan. Secara umun faktor-faktor yang mendukung jalannya program-program kerja kami antara lain:

a. Dukungan dan kerja sama antar anggota KKN yang sangat sangat baik dalam pelaksanaan program

b. Dukungan dari berbagai pihak pemerintahan daerah, diantaranya Kepala Desa beserta jajarannya, RW, RT dan Karang Taruna Desa yang senantiasa memberi masukan dan dukungan terhadap terlaksananya program kerja kami.

c. Masyarakat Desa Cibitung Wetan yang sangat mendukung adanya program KKN akan dijalankan di Desanya.

d. Kegiatan KKN 40 di desa cibitung wetan mendapat sambutan yang baik dari masyarakat setempat yaitu dengan dukungan moril maupun materi demi kelancaran pelaksanaan kegiatan KKN. Selain itu, KKN ini merupakan ajang pembuktian bagi elite intelektual untuk terjun langsung ke masyarakat, sesuai dengan Tri Darma Perguruan Tinggi, hasil mempelajari teori adalah apikasi mahasiswa diharapkan lebih dekat dengan masyarakat, mampu belajar dari masyarakat, membantu memecahkan permasalahan yang ada, mengabdi dan memberdayakan masyarakat.

e. Dampak bagi mahasiswa diantaranya jiwa sosial mahasiswa lebih terbangun, berbagai potensi yang dimiliki setiap mahasiswa tersalurkan, dan masih banyak lagi. Sedangkan dampak bagi masyarakat diantaranya Dicapainya akselerasi dan efektifitas program pembagunan yang ditandai oleh semakin baiknya kualitas kehidupan masyarakat dan semakin meningkatnya partisipasi dan pemberdayaan masyarakat dalam program kesehatan, pendidikan, hukum, ekonomi mandiri yang ditunjukan dengan peningkatan pengetahuan, sikap, dan keterampilan serta usaha mereka setelah mengikuti pembelajaran dalam rangka meningkatkan wirausaha dengan pemanfaatan sumber daya alam. 


\section{REFERENSI}

Administrasi profil Desa Cibitung Wetan

Petunjuk pelaksanaan KKN Tematik Terintegrasi 2018, LPPM UIKA BOGOR 2018, UIKA Press

Nana Sudjana. 2016. Penilaian Hasil Belajar Mengajar. Bandung. Remaja Rosdakarya.
Suharsismi Arikunto. 2017. Dasar-dasar Evaluasi Pendidikan. Jakarta. Bumi Aksara

Kamus Besar Bahasa Indonesia. [Online]. Tersedia di kbbi.kemdikbud.go.id/entri/religius. Diakses 10 September 2018 